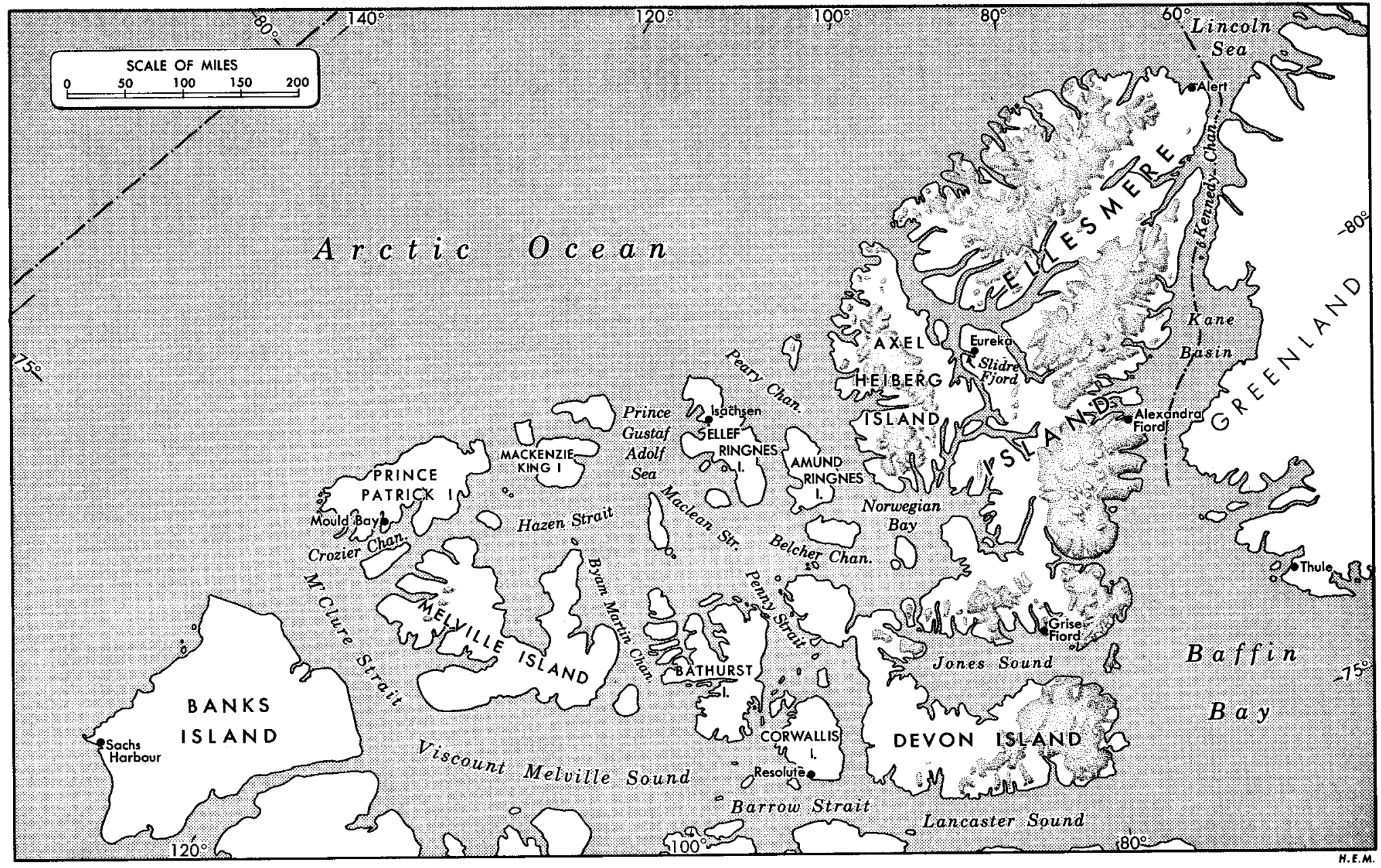

Fig. 1. General map of the Queen Elizabeth Islands (after Taylor 1955). 


\title{
FORMATION, GROWTH, AND DECAY OF SEA-ICE IN THE CANADIAN ARCTIC ARCHIPELAGO
}

\author{
Michael A. Bilello*
}

\section{Introduction}

Various stages in the growth of sea-ice are mainly dependent upon the meteorological elements. Relationships between weather and ice conditions may provide methods for predicting ice formation, growth, and decay. This report is concerned with studies that associate formation and decay of sea-ice with air temperatures, and its rate of accretion with air temperatures and snow depths.

Investigations usually indicate that air temperature, snow depth, and initial ice thickness are the most important data required to predict the thickening of the ice sheet. Most formulas derived empirically (Bydin 1933, Lebedev 1938) express the vertical growth of sea-ice as:

$$
\text { where: } \begin{aligned}
\mathrm{I} & =\mathrm{a}(\Sigma \theta)^{\mathrm{b}} \\
\mathrm{I} & =\text { ice thickness } \\
\mathrm{\Delta \theta} & =\text { sum of negative daily air temperature } \\
\mathrm{a} \text { and } \mathrm{b} & =\text { constants. }
\end{aligned}
$$

In part, the constants in the equation represent the influence of average snow conditions on the rate of ice growth. The effect of non-uniform or fluctuating snow depths on ice growth is not considered in equations of this type.

In this report, equations relating the accretion of sea-ice to standard meteorological data are derived empirically from observations made at stations located in the Canadian Arctic. The equations differ from existing formulas in that (1) they are differential in form, to permit the calculation of ice growth by increments, and (2) they contain a separate term that allows for variations in snow depth.

The methods applied to predict freeze-up were derived from a study of the relationship between ice formation in the Baltic Sea and weighted mean daily air temperature (Rodhe 1952).

The data used in this report were obtained from five localities in the Canadian Arctic Archipelago (Queen Elizabeth Islands) (Fig. 1). The meteorological observations and snow depth-ice thickness measurements were made by personnel assigned to these stations by the U. S. Weather Bureau

*Climatic and Environmental Research Branch, U.S. Army Cold Regions Research and Engineering Laboratory, Corps of Engineers, Wilmette, Ill., U.S.A. 
and the Meteorological Branch, Canada Department of Transport. The stations and the years for which data on ice growth are available are as follows:

\begin{tabular}{|c|c|}
\hline Alert, N.W.T. & $\begin{array}{l}1950-1 \text { to } 1952-3 \text {, and } \\
1954-5 \text { to } 1956-7\end{array}$ \\
\hline Eureka, N.W.T. & $\begin{array}{l}1947-8 \text { to } 1951-2,1953-4 \\
1954-5 \text { and } 1956-7\end{array}$ \\
\hline Isachsen, N.W.T. & $\begin{array}{l}1948-9 \text { to } 1952-3 \text {, and } \\
1954-5 \text { to } 1956-7\end{array}$ \\
\hline Mould Bay, N.W.T. & $\begin{array}{l}1949-50,1951-2, \text { and } \\
1953-4 \text { to } 1956-7\end{array}$ \\
\hline Resolute, N.W.T. & $1947-8$ to $1956-7$ \\
\hline
\end{tabular}

The location of each station, the names of surrounding water bodies and the approximate water depths where the ice thickness measurements were made are listed in Appendix A.

\section{Sea-ice formation}

The term "freeze-up" as used in this paper defines the date when ice first forms. When the body of water becomes completely covered with ice, the term "freeze-over" is used. The observers at the stations often found it difficult to determine correct dates of ice formation to fit the terms. For example, an observer at Alert, Mould Bay, and Eureka pointed out that during the falls of 1951 and 1954 it was practically impossible to establish firm dates for freeze-up and freeze-over. He found that sudden squalls and strong tidal currents in small bodies of water affect freeze-over considerably. Excerpts from a diary kept during August and September at these stations were submitted to bear out the unstable ice conditions. Except during unusual wind or current conditions, freeze-over generally occurred soon after freeze-up. The longest intervals were observed at Resolute Bay.

The available observed dates of freeze-up at the arctic weather stations are given in Table 1. Most of the observations were obtained as a part of the program for measuring sea-ice thickness. A search through Miscellaneous Notes (Records of Meteorological Observations, Canada Department of Transport) provided additional information, but the record for dates of freeze-up at these stations is still not complete.

Freeze-up at Resolute Bay in the 9 years of record occurred between September 12 and 26. Reports of rough ice and the occasional break-up of new ice in Resolute Bay indicate that a considerable amount of ice movement can occur at this locality during the period of ice formation.

At Eureka air temperatures were observed to decrease rapidly during September (U. S. Weather Bureau, Climatological Summary, Eureka). This rapid change accompanied by light winds results in a well defined freeze-up and comparatively smooth ice surface conditions. For the six years of available record, freeze-up on Slidre Fiord at Eureka was observed between September 6 and 21. 
Table 1. Observed freeze-up dates, accumulated degree-days of frost (below $-1.8^{\circ} \mathrm{C}$.) and frost-days.

\begin{tabular}{|c|c|c|c|c|c|}
\hline Station & Year & $\begin{array}{l}\text { Beginning date of } \\
\text { continuous frost } \\
\left(\text { below }-1.8^{\circ} \mathrm{C} .\right)\end{array}$ & $\begin{array}{l}\text { Observed } \\
\text { freeze-up } \\
\quad \text { date }\end{array}$ & $\begin{array}{l}\text { Number of } \\
\text { frost-days } \\
\text { (Column } 4 \text { minus } \\
\text { column 3) }\end{array}$ & $\begin{array}{l}\text { Accumulated } \\
\text { degree-days of frost } \\
\left(\text { below }-1.8^{\circ} \mathrm{C} .\right)\end{array}$ \\
\hline \multirow[t]{2}{*}{ Alert } & $\begin{array}{l}1956 \\
1954 \\
1952 \\
1951\end{array}$ & $\begin{array}{l}\text { Aug. } 21 \\
\text { Sept. } 13 \\
\text { Aug. } 27 \\
\text { Aug. } 28\end{array}$ & $\begin{array}{l}\text { Aug. } 27 \\
\text { Sept. } 17 \\
\text { Aug. } 30 \\
\text { Aug. } 31\end{array}$ & $\begin{array}{l}6 \\
4 \\
3 \\
3\end{array}$ & $\begin{array}{r}9.1 \\
12.8 \\
15.2 \\
12.4\end{array}$ \\
\hline & & & Mean $=$ & 4 & 12.4 \\
\hline \multirow[t]{2}{*}{ Eureka } & $\begin{array}{l}1956 \\
1954 \\
1953 \\
1951 \\
1950 \\
1947\end{array}$ & $\begin{array}{l}\text { Aug. } 29 \\
\text { Sept. } 15 \\
\text { Sept. } 5 \\
\text { Sept. } 6 \\
\text { Sept. } 3 \\
\text { Sept. } 3\end{array}$ & $\begin{array}{l}\text { Sept. } 6 \\
\text { Sept. } 21 \\
\text { Sept. } 13 \\
\text { Sept. } 13 \\
\text { Sept. } 7 \\
\text { Sept. } 15\end{array}$ & $\begin{array}{r}8 \\
6 \\
8 \\
7 \\
4 \\
12 \\
\end{array}$ & $\begin{array}{l}17.3 \\
19.3 \\
23.8 \\
16.2 \\
14.5 \\
16.7\end{array}$ \\
\hline & & & Mean $=$ & 7.5 & 18.0 \\
\hline \multirow[t]{2}{*}{ Isachsen } & $\begin{array}{l}1956 \\
1952 \\
1951 \\
1950 \\
1948\end{array}$ & $\begin{array}{l}\text { Aug. } 21 \\
\text { Aug. } 27 \\
\text { Sept. } 3 \\
\text { Sept. } 3 \\
\text { Aug. } 20\end{array}$ & $\begin{array}{l}\text { Aug. } 29 \\
\text { Aug. } 29 \\
\text { Sept. } 6 \\
\text { Sept. } 5 \\
\text { Aug. } 24\end{array}$ & $\begin{array}{l}8 \\
2 \\
3 \\
2 \\
4\end{array}$ & $\begin{array}{r}12.8 \\
5.3 \\
11.3 \\
5.3 \\
8.3\end{array}$ \\
\hline & & & Mean $=$ & 3.8 & 8.6 \\
\hline \multirow[t]{2}{*}{ Mould Bay } & $\begin{array}{l}1956 \\
1955 \\
1951 \\
1948\end{array}$ & $\begin{array}{l}\text { Aug. } 26 \\
\text { Aug. } 31 \\
\text { Sept. } 10 \\
\text { Aug. } 26\end{array}$ & $\begin{array}{l}\text { Sept. } 1 \\
\text { Sept. } 7 \\
\text { Sept. } 15 \\
\text { Sept. } 1\end{array}$ & $\begin{array}{l}6 \\
7 \\
5 \\
6\end{array}$ & $\begin{array}{r}16.0 \\
4.7 \\
6.0 \\
9.1\end{array}$ \\
\hline & & & Mean $=$ & 6 & 9.0 \\
\hline Resolute & $\begin{array}{l}1956 \\
1955 \\
1954 \\
1953 \\
1952 \\
1950 \\
1949 \\
1948 \\
1947\end{array}$ & $\begin{array}{c}\text { Aug. } 28 \\
\text { Sept. } 9 \\
\text { Sept. } 14 \\
\text { Sept. } 6 \\
\text { Aug. } 28 \\
\text { Sept. } 12 \\
\text { Sept. } 7 \\
\text { Sept. } 12 \\
\text { No temp. data } \\
\text { for Sept. }\end{array}$ & $\begin{array}{l}\text { Sept. } 12 \\
\text { Sept. } 23 \\
\text { Sept. } 26 \\
\text { Sept. } 20 \\
\text { Sept. } 17 \\
\text { Sept. } 21 \\
\text { Sept. } 15 \\
\text { Sept. 18 } \\
\text { Sept. 20 } \\
\text { Mean = }\end{array}$ & \begin{tabular}{r}
15 \\
14 \\
12 \\
14 \\
20 \\
9 \\
8 \\
6 \\
\multicolumn{1}{c}{ No } \\
12.2
\end{tabular} & $\begin{array}{c}36.3 \\
41.6 \\
11.7 \\
43.7 \\
37.4 \\
48.3 \\
41.1 \\
26.3 \\
\text { temp. data for Sept. } \\
35.8\end{array}$ \\
\hline
\end{tabular}

In 1954, freeze-up at Resolute, Eureka, and Alert occurred unusually late in September. This delay apparently was associated with the abnormally high air temperatures observed throughout the Canadian Arctic Archipelago during that month (Fig. 2), and implies that any precise prediction of ice formation for this area may be largely dependent on the accuracy in forecasting the air temperatures during September.

Sea-ice in the bays at Isachsen, Mould Bay, and Alert does not always completely melt or drift clear in the summer. However, areas of open water do develop around these stations and freeze-up applies to formation of new ice over these areas. The precise effect of old ice on the formation of new ice could not be determined. It appears that fewer degree-days of frost are 
required for freeze-up where old ice is present than at stations where ice completely melts or drifts away in the summer. This difference is probably due to lower water temperatures where old ice is present.

Freeze-up at Alert and Isachsen occurs as early as the last week of August. Except for unusually warm Septembers, as at Alert in 1954, freezeup at these stations can be expected by September 8. At Mould Bay freezeup occurred in the first 15 days of September during the years of record.

Few descriptions of the surface smoothness of newly formed ice sheets are contained in the records. Personal observation and conversation with station personnel indicate that surface smoothness varied to some extent for each year and location. Depending on the bulk of pack ice, and the direction and velocity of the wind during freeze-up, the bays and fiords may be clear or partly filled with bergs, old floes, rafted ice, etc. Tides and currents also disrupt thin ice sheets. In time, a cover of snow may hide small hummocks and minor cracks in the ice. A snow cover may create the impression (especially from the air) that the ice surface is smooth.

\section{Methods for predicting freeze-up using air temperatures}

Lee and Simpson (1954) present a method of predicting sea-ice formation that requires considerable climatological and oceanographic data for the area in question. Since such data are not generally available, this study was directed toward methods that might establish a suitable relationship between ice formation and air temperatures only.

Fukutomi (1950) developed an equation relating the freezing date of coastal waters in cold areas to air temperatures. In a later report (1955), he found the equation to be approximately applicable in specific cases, but the general value of part of the expression varied slightly for the Okhotsk, Japan, and arctic seas. The method was tested using data from the five stations covered in this study and was found to be applicable where approximate mean dates of freeze-up are required and only mean monthly air temperatures are available.

Ostman and Nusser as reviewed by Rodhe (1952) related sea-ice formation in the Baltic Sea and the Gulf of Bothnia to air temperatures. Ostman obtained the summation of degree-days of frost below $0^{\circ} \mathrm{C}$. (numerical accumulation of differences between the mean daily air temperatures and a selected base), beginning with the first frost in fall or early winter, and correlated this "frost-sum" with ice formation in the adjacent sea. However, temperatures above $0^{\circ} \mathrm{C}$., which may intervene before ice formation begins, are not taken into consideration. Nusser correlated ice formation to the number of days with mean temperatures below $0^{\circ} \mathrm{C}$. (frost days) which immediately preceded the date of occurrence. If the series of days was interrupted by only one day having a mean temperature of $0^{\circ} \mathrm{C}$. or above, the day was then omitted. If the interruption consisted of two or more days, then the series of frost days before and after were considered as two differ- 
ent frost periods and the first one was disregarded. The method, consequently, does not indicate for certain whether a particular frost period will produce ice.

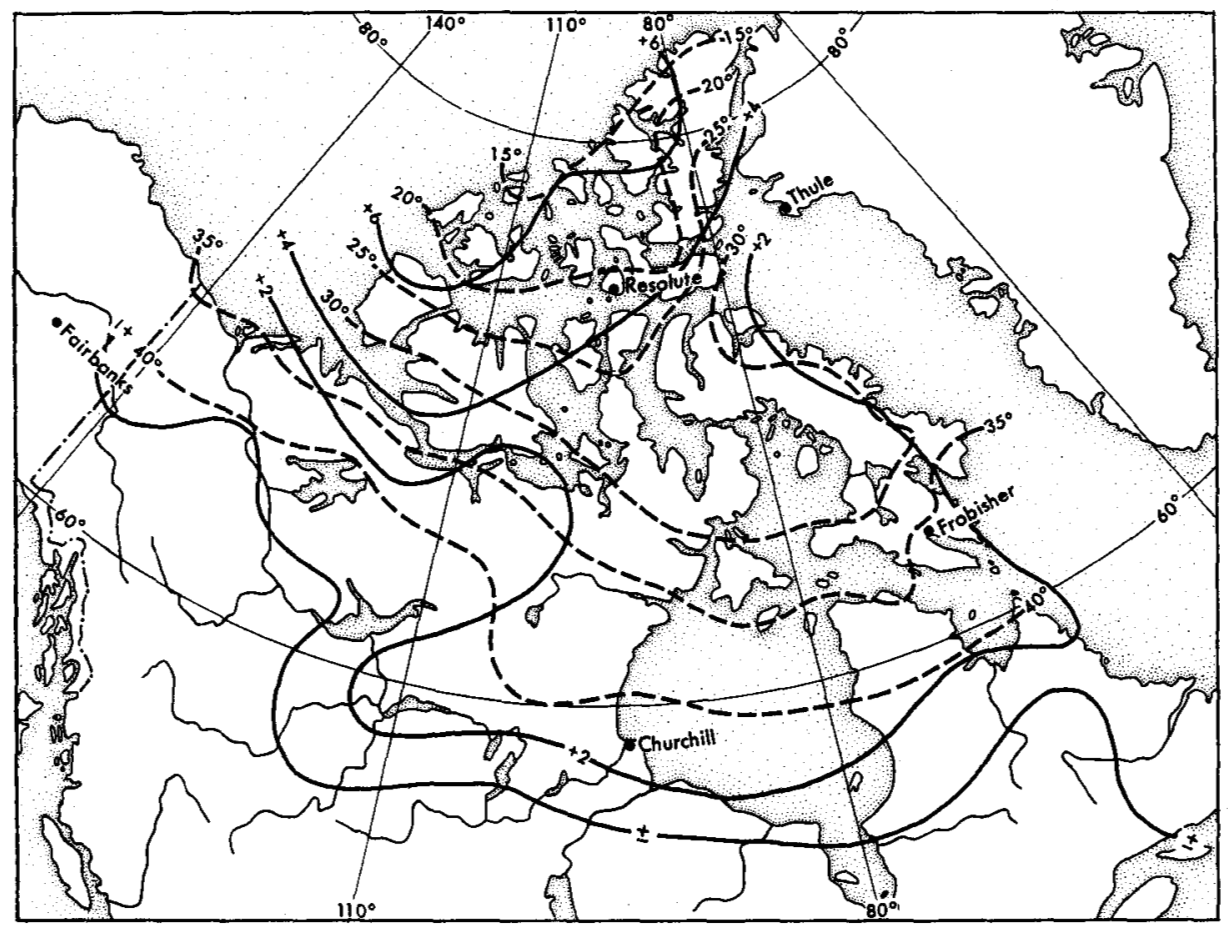

Fig. 2. Departure from mean monthly air temperature ( ${ }^{\circ} \mathrm{F}$.) for September 1954. Dashed lines are the mean monthly values, solid lines are the departures (from: Anon. 1954).

These "frost-sum" and "frost-days" methods were combined and applied to data from the stations used in this study. The accumulated degree-days of frost and the number of frost-days (up to the time of freeze-up) are given for each station (Table 1). The mean values for each station are compared (Fig. 3). The diagram shows the average degree of coldness and the length of time required for ice to form at each station, but does not show the starting date of the effective frost period nor the effect of intervening periods of above-freezing temperatures. Since the water salinity in the area, if no ice is present, is about 32.0 to $33.0 \%,-1.8^{\circ} \mathrm{C}$. was used as the freezing point. (Sverdrup et al. 1942).

Rodhe (1952) presents a relationship between weighted mean daily temperature and ice formation, which does not depend solely on temperatures during a limited period of time. The mathematical theory is logically based upon a simplified physical law of heat flow between the sea surface and the air. The results of the investigation provide a method by which the date of ice formation at a particular locality can be computed objectively from daily air temperatures. The procedure is to determine by trial and 
error which value of $k^{-1}$, using the expression $1-e^{-k}$, provides the correct numerical sequence that must attain the value $-1.8^{\circ} \mathrm{C}$. on the exact day freeze-up occurred. By associating the time when the sequence reduces to $-1.8^{\circ} \mathrm{C}$. (or $0^{\circ} \mathrm{C}$. for fresh water) with the dates of previously observed freeze-up, $\mathrm{k}^{-1}$, termed the " $\mathrm{Z}$ " function, is determined for each location.

For example, let $\mathrm{k}^{-1}=20.0$, then $\mathrm{e}^{-\mathrm{k}}=\mathrm{e}^{-0.05}=0.951$, and $1-\mathrm{e}^{-\mathrm{k}}=$ 0.049 . Initially a mean daily or monthly temperature that occurred at a period some months before freeze-up is selected (the mean monthly air temperature for June was used as the starting point in this study). This initial value is subtracted from the mean daily air temperature for the following day. The difference (which can be plus or minus) is multiplied by the constant 0.049 . This weighted correction is then added arithmetically to the initial value. The adjusted value is then subtracted from the mean daily air temperature for the next day, and the difference is again multiplied by 0.049. The new correction is applied to the adjusted value and the procedure repeated. The computation in effect weighs each daily air temperature gradually, incorporating the influence of warm or cool summers and sudden cold or warm periods prior to freeze-up.

A sample computation follows where $\mathrm{k}^{-1}=20.0$ and the starting temperature $=+3.0^{\circ} \mathrm{C} .:$

\begin{tabular}{|c|c|c|c|c|}
\hline$\underset{\text { Date }}{\mathrm{A}}$ & $\underset{\text { Mean doily }}{\mathrm{B}}=$ & $\stackrel{\mathrm{C}}{(B-E)}$ & $(C \times \stackrel{D}{0.049)}$ & $\stackrel{\stackrel{E}{+} D)}{(E+)^{\prime}}$ \\
\hline $\begin{array}{r}\text { Mean for mont } \\
\text { July } 1 \\
2 \\
3 \\
4\end{array}$ & $\begin{array}{l}+5.5 \\
+8.2 \\
+2.6 \\
+6.0\end{array}$ & $\begin{array}{l}+2.50 \\
+5.08 \\
-0.77 \\
+2.67\end{array}$ & $\begin{array}{l}+.12 \\
+.25 \\
-.04 \\
+.13\end{array}$ & $\begin{array}{l}+3.00^{\circ} \mathrm{C} . \\
+3.12 \\
+3.37 \\
+3.33 \\
+3.46\end{array}$ \\
\hline
\end{tabular}

The computation continues up to the reported date of freeze-up. If on that date the value in column $\mathrm{E}$ is equal to the freezing point of the water then the " $\mathrm{Z}$ " function for that locality is equal to 20.0. If the value in column $\mathrm{E}$ is higher than the freezing point, then " $\mathrm{Z}$ " is decreased to alter the rate of change in column $E$. In order to obtain greater certainty in the value of " $\mathrm{Z}$ ", it may be necessary to use 2 or 3 years of record when freeze-up occurred at a particular place. When " " has been determined, reasonably accurate prediction of freeze-up date becomes only a matter of good air temperature forecasts. A full mathematical treatment of the theory is available in Rodhe's Report (1952).

The following are the computed values for " $Z$ " based on the freezing point of $-1.8^{\circ} \mathrm{C}$. for the five stations in this study:

\begin{tabular}{|c|c|c|}
\hline Station & & "Z" function \\
\hline Alert & & 10.6 \\
\hline Eureka & & 9.9 \\
\hline Isachsen & & 8.4 \\
\hline Mould Bay & 8 & 9.9 \\
\hline Resolute & & 21.0 \\
\hline
\end{tabular}


Except for two cases in 25 station-years of record used in the above analysis, the "Z" functions shown yielded freeze-up dates correct to within 3 days of the observed dates (Table 2). Although the method is obviously still dependent upon the prognosis of air temperature, the task of predicting ice formation has been successfully limited to a single variable.

Fig. 3. Association of accumulated degree-days of frost (below $-1.8^{\circ} \mathrm{C}$.) and "frostdays".

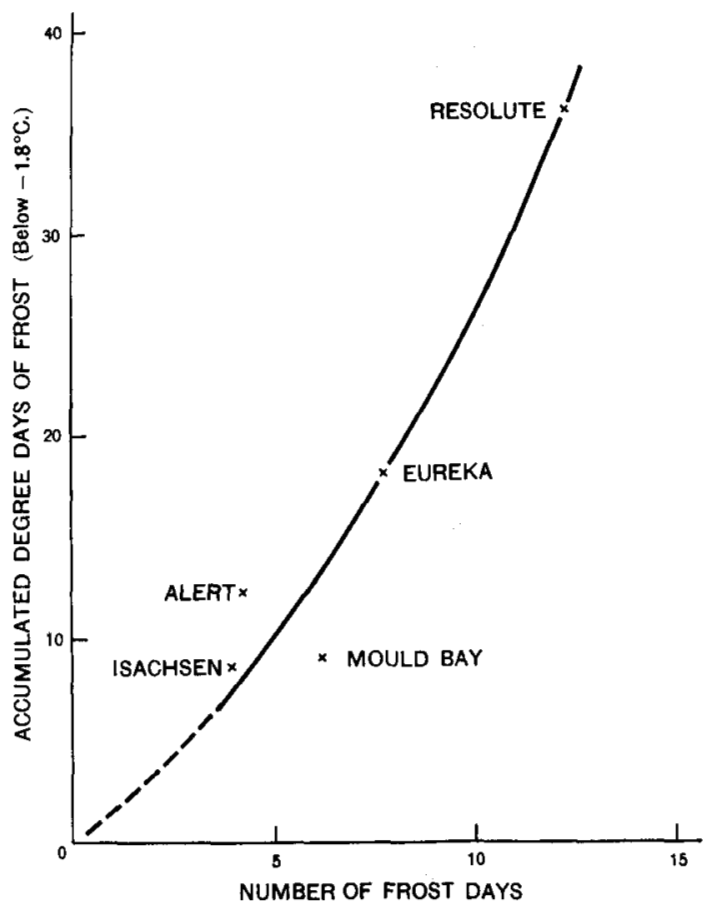

Growth of sea-ice

The techniques used to measure sea-ice thickness (App. B) require that the observer walks out on the ice. First reports each year therefore depended upon shore conditions, ice strength, whether vehicles were being used, and the courage of the observer. Few observations for thicknesses less than $10 \mathrm{~cm}$. were made, and reports usually were not received until approximately $20 \mathrm{~cm}$. of ice had accumulated. The frequency of observations varied from year to year. Weekly observations provided smooth icegrowth curves, whereas monthly readings produced flat, poorly defined curves. Another advantage of the more frequent observations was that erroneous measurements were readily detected.

Observations on ice thickness and snow depth were made in a general region rather than at exact localities. Large discrepancies did not result from this practice unless there were appreciable differences in the depth of snow, or parts consisting of old or rafted ice were unintentionally being measured.

It became apparent after drawing the accumulative ice curves that some adjustments would be necessary for general smoothness. It was decided to 
tolerate $a \pm 10 \mathrm{~cm}$. correction for individual observations, but to maintain a maximum of $\pm 10 \mathrm{~cm}$. adjustment for the mass curve.

Using the ice thickness data obtained at each station, smooth curves for ice growth were drawn. The maximum seasonal growth of ice was observed at Isachsen, where $269 \mathrm{~cm}$. was measured in April 1950; the minimum was $149 \mathrm{~cm}$. at Resolute measured in April-May 1953 (Fig. 4). Corresponding snow depths are also shown in Fig. 4. The amount of ice that accumulates differs from year to year, as well as from station to station. These differences are the result of variations in tides, currents, other oceanographic conditions, and numerous meteorological processes. The lack of data for most of these parameters however made it necessary to confine the study to an analysis of the effect of air temperatures and snow depths on the growth of sea-ice. These meteorological variables are the ones most readily obtained from regularly scheduled teletype transmissions, thus permitting application of the equation to currently available data.

Table 2. Observed versus computed freeze-up dates.

\begin{tabular}{|c|c|c|c|}
\hline Station & Year & $\begin{array}{c}\text { Observed } \\
\text { freeze-up date }\end{array}$ & $\begin{array}{c}\text { Computed } \\
\text { freeze-up date }\end{array}$ \\
\hline Alert & $\begin{array}{l}1956 \\
1954 \\
1952 \\
1951\end{array}$ & $\begin{array}{l}\text { Aug. } 27 \\
\text { Sept. } 17 \\
\text { Aug. } 30 \\
\text { Aug. } 31\end{array}$ & $\begin{array}{l}\text { Aug. } 30-31 \\
\text { Sept. } 16 \\
\text { Aug. } 29-30 \\
\text { Aug. } 31\end{array}$ \\
\hline Eureka & $\begin{array}{l}1956 \\
1954 \\
1953 \\
1951 \\
1950 \\
1947\end{array}$ & $\begin{array}{c}\text { Sept. } 6 \\
\text { Sept. } 21 \\
\text { Sept. } 13 \\
\text { Sept. } 13 \\
\text { Sept. } 7 \\
\text { August temps. missing }\end{array}$ & $\begin{array}{l}\text { Sept. } 6 \\
\text { Sept. } 21 \\
\text { Sept. } 11-12 \\
\text { Sept. } 12 \\
\text { Sept. } 10\end{array}$ \\
\hline Isachsen & $\begin{array}{l}1956 \\
1952 \\
1951 \\
1950 \\
1948\end{array}$ & $\begin{array}{l}\text { Aug. } 29 \\
\text { Aug. } 29 \\
\text { Sept. } 6 \\
\text { Sept. } 5 \\
\text { Aug. } 24\end{array}$ & $\begin{array}{lr}\text { Aug. } 28 \\
\text { Aug. } 29 \\
\text { Sept. } 5 \\
\text { Sept. } 5 \\
\text { Aug. } 24\end{array}$ \\
\hline Mould Bay & $\begin{array}{l}1956 \\
1955 \\
1951 \\
1948\end{array}$ & $\begin{array}{l}\text { Sept. } 1 \\
\text { Sept. } 7 \\
\text { Sept. } 15 \\
\text { Sept. } 1\end{array}$ & $\begin{array}{lr}\text { Aug. } & 31 \\
\text { Sept. } & 7 \\
\text { Sept. } 16 \\
\text { Sept. } 1\end{array}$ \\
\hline Resolute & $\begin{array}{l}1956 \\
1955 \\
1954 \\
1953 \\
1952 \\
1950 \\
1948 \\
1947\end{array}$ & $\begin{array}{c}\text { Sept. } 12 \\
\text { Sept. } 23 \\
\text { Sept. } 26 \\
\text { Sept. } 20 \\
\text { Sept. } 17 \\
\text { Sept. } 21 \\
\text { Sept. } 18 \\
\text { September temps. missing }\end{array}$ & $\begin{array}{l}\text { Sept. } 12-13 \\
\text { Sept. } 20-21 \\
\text { Sept. } 29-30 \\
\text { Sept. } 20 \\
\text { Sept. } 18 \\
\text { Sept. } 20 \\
\text { Sept. } 20\end{array}$ \\
\hline
\end{tabular}

The cumulative degree-days of frost as related to the growth of ice were computed using a base of $-1.8^{\circ} \mathrm{C}$. Mean daily air temperatures were computed from the maximum and minimum temperatures for the day. As daily air temperatures at these high-latitude stations rarely go above 
$-1.8^{\circ} \mathrm{C}$. (after freeze-up), the effect of intervening thaw periods on ice growth can be neglected.

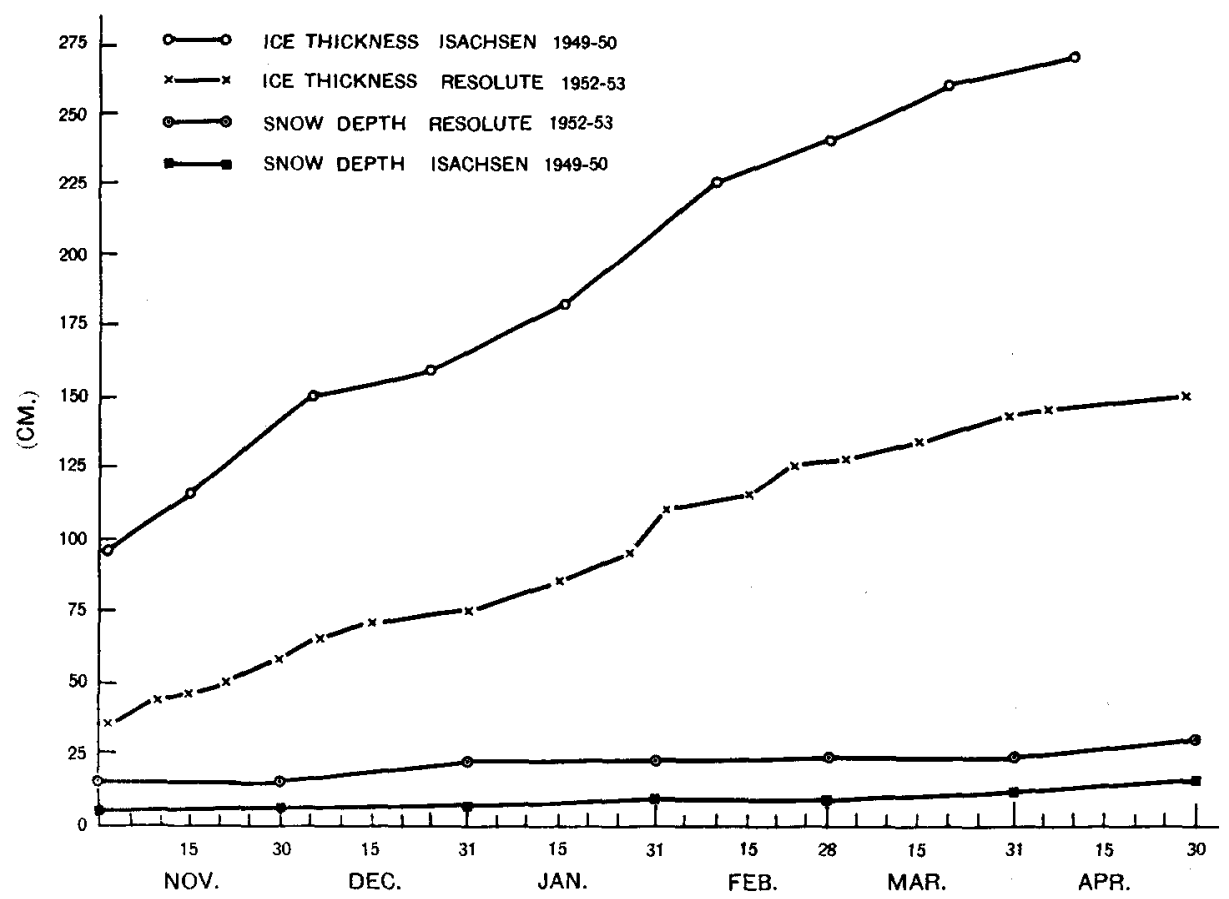

Fig. 4. Maximum and minimum sea-ice growth curves.

Fig. 5. Conversion of accumulated degree-days of frost using the base of $0^{\circ} \mathrm{C}$. or $-1.8^{\circ} \mathrm{C}$.

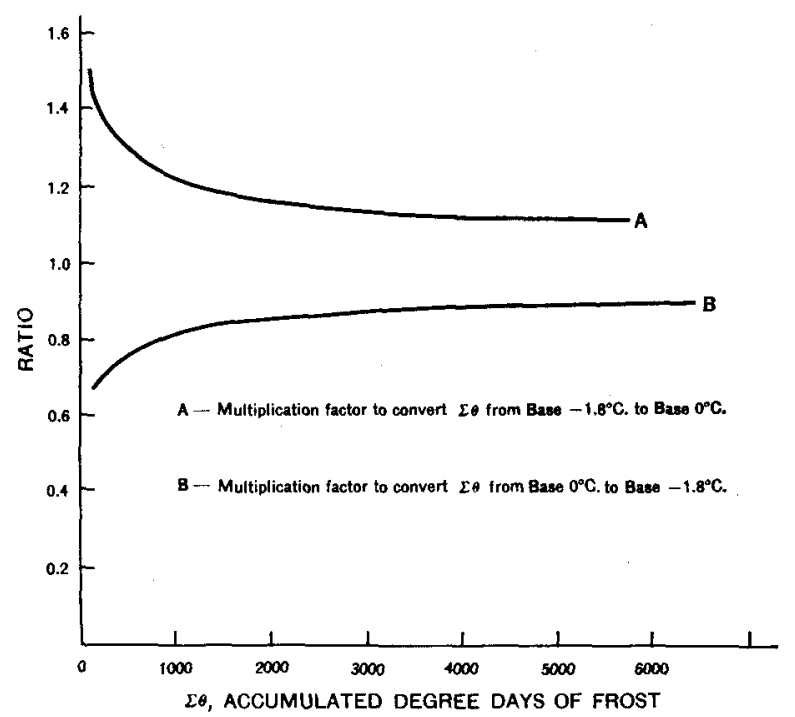

Accumulated degree-days of frost for most of the published studies on ice growth were computed using a base of $0^{\circ} \mathrm{C}$. To facilitate computation or to make comparisons possible, direct conversion from the $0^{\circ} \mathrm{C}$. base to $-1.8^{\circ} \mathrm{C}$. or vice versa may be obtained from the ratio curves shown in 
Figure 5. These ratios, however, are applicable only as an average for the Canadian stations discussed in this report.

The average winter accumulation of degree-days of frost is plotted in Figure 6 for each station. Up to the end of May the curves show Eureka as having the largest (6830) and Resolute the smallest (5680) average accumulation. Year to year variations in accumulated degree-days of frost at each station would influence the total amount of ice that accumulates.

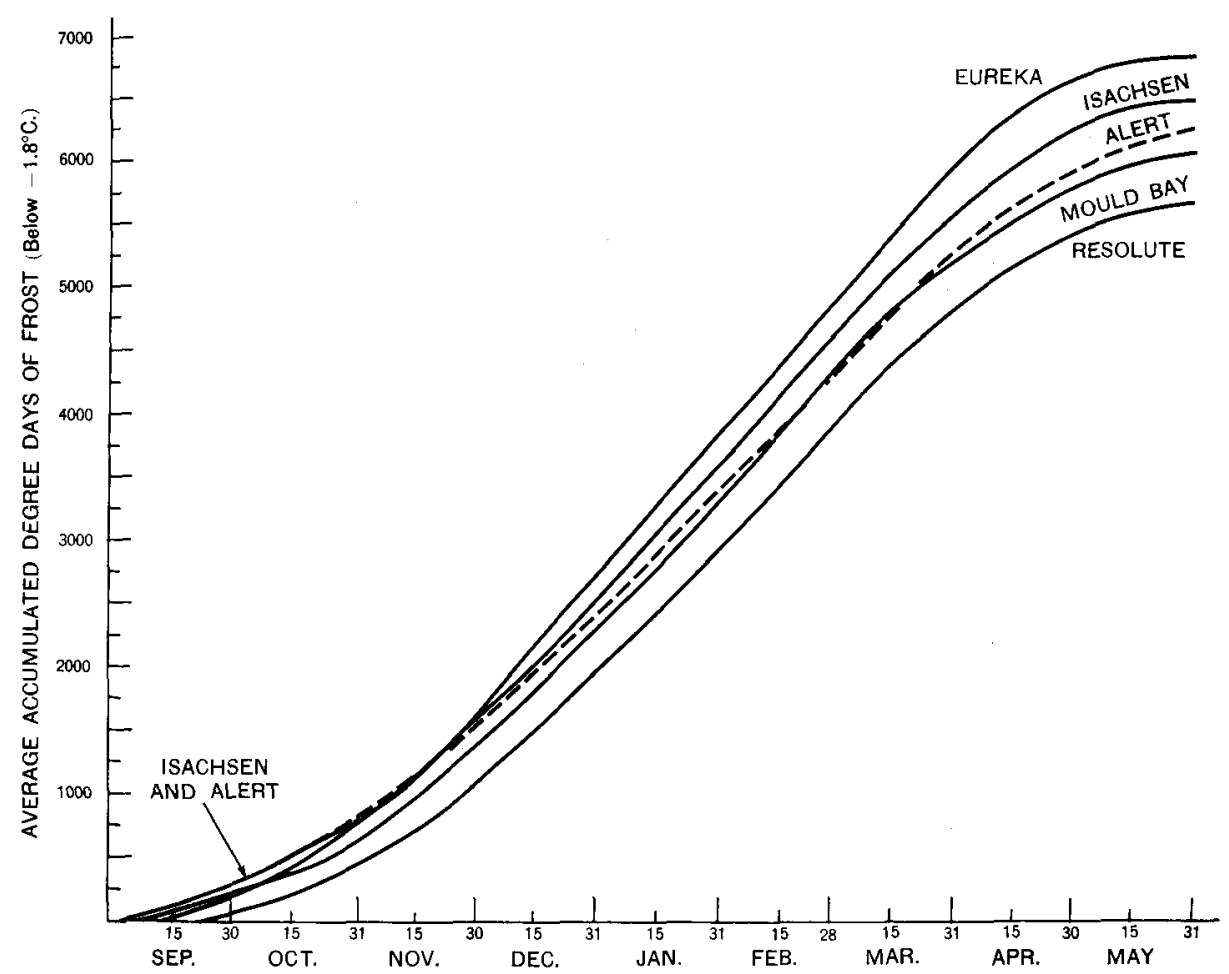

Fig. 6. Average accumulated degree-days of frost (below $-1.8^{\circ} \mathrm{C}$.).

Figs. 7-11, a series of smooth curves for each station, show the thickness of sea ice as related to accumulated degree-days of frost and depth of snow on the ice. Data on snow were either missing or incomplete for some periods of the record. To supplement the data, information on depth of snow on the ground and daily snowfall amounts was obtained from the Monthly Record, Meteorological Observations in Canada (Department of Transport). The marked effect of snow cover on ice growth forms the basis for the derivation of an ice-growth equation, (8), which contains a separate term to allow for variations in snow depth.

Equations for predicting sea-ice growth using air temperatures

Callaway (1954) analyzes the numerous variables in equations developed by Kolesnikov (1946) and evaluates their separate effects. The results, in part, point out the pronounced effect of air temperature, snow thickness, and ice thickness on the rate of ice accumulation. 


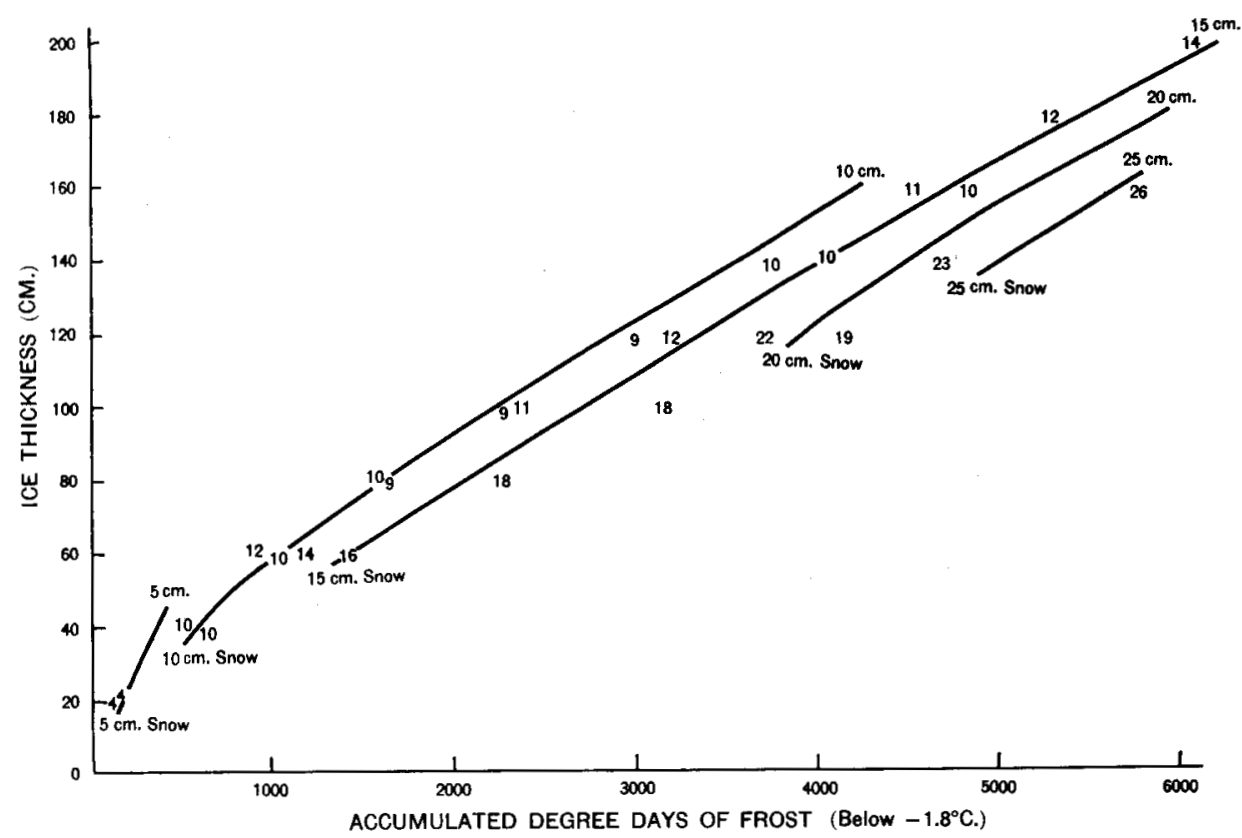

Fig. 7. Relationship between ice thickness, accumulated degree-days of frost (below $-1.8^{\circ} \mathrm{C}$.) and snow depth (numbers on curves) at Alert.

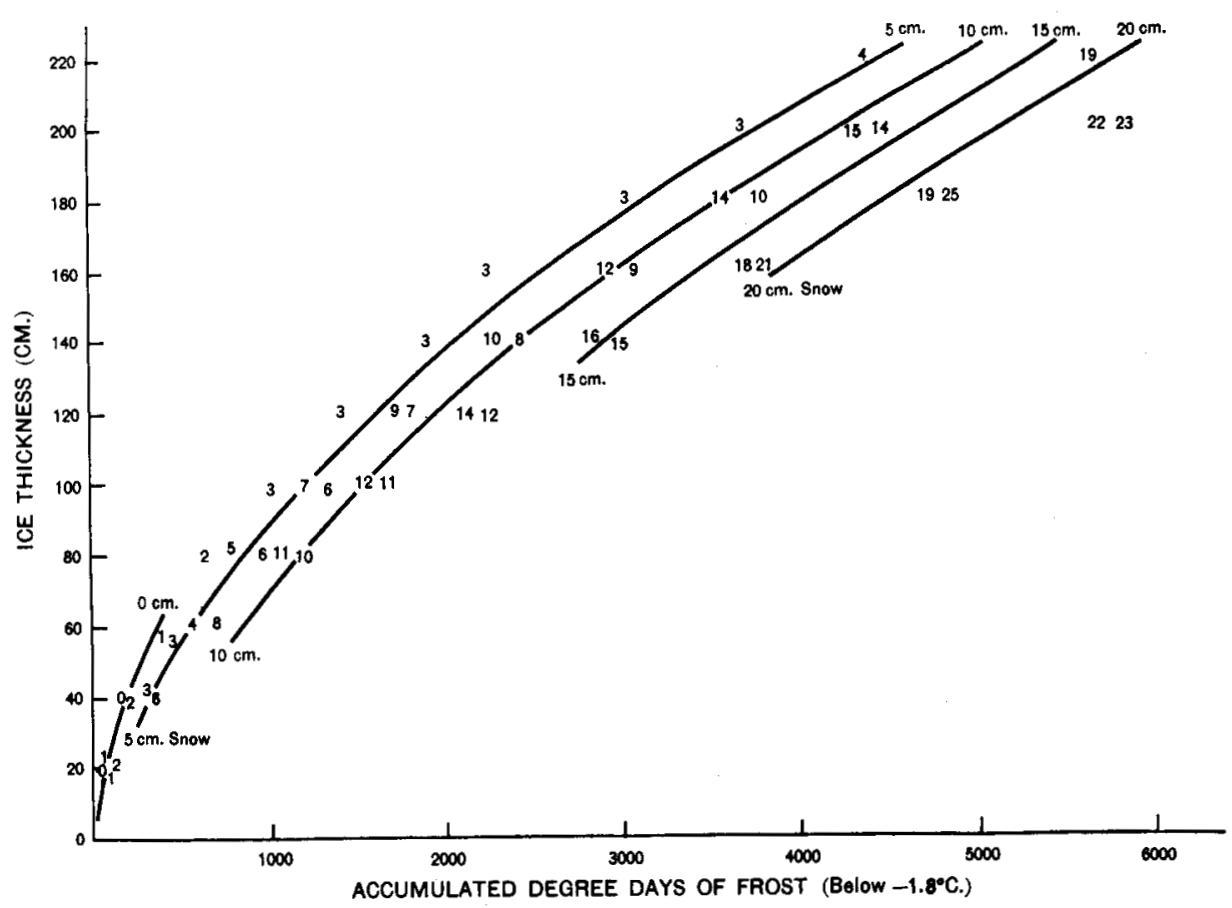

Fig. 8. Relationship between ice thickness, accumulated degree-days of frost (below $-1.8^{\circ} \mathrm{C}$.) and snow depth (numbers on curves) at Eureka. 


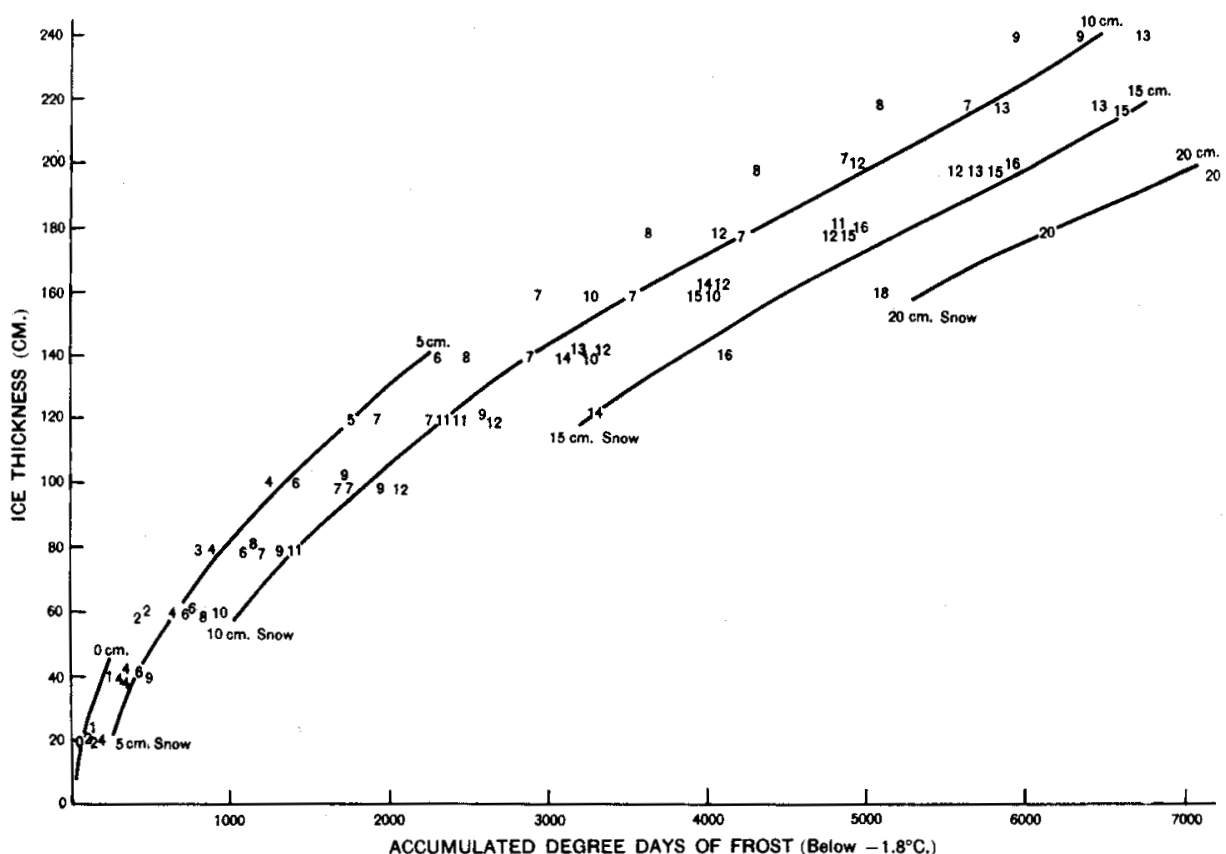

Fig. 9. Relationship between ice thickness, accumulated degree-days of frost (below $-1.8^{\circ} \mathrm{C}$.) and snow depth (numbers on curves) at Isachsen.

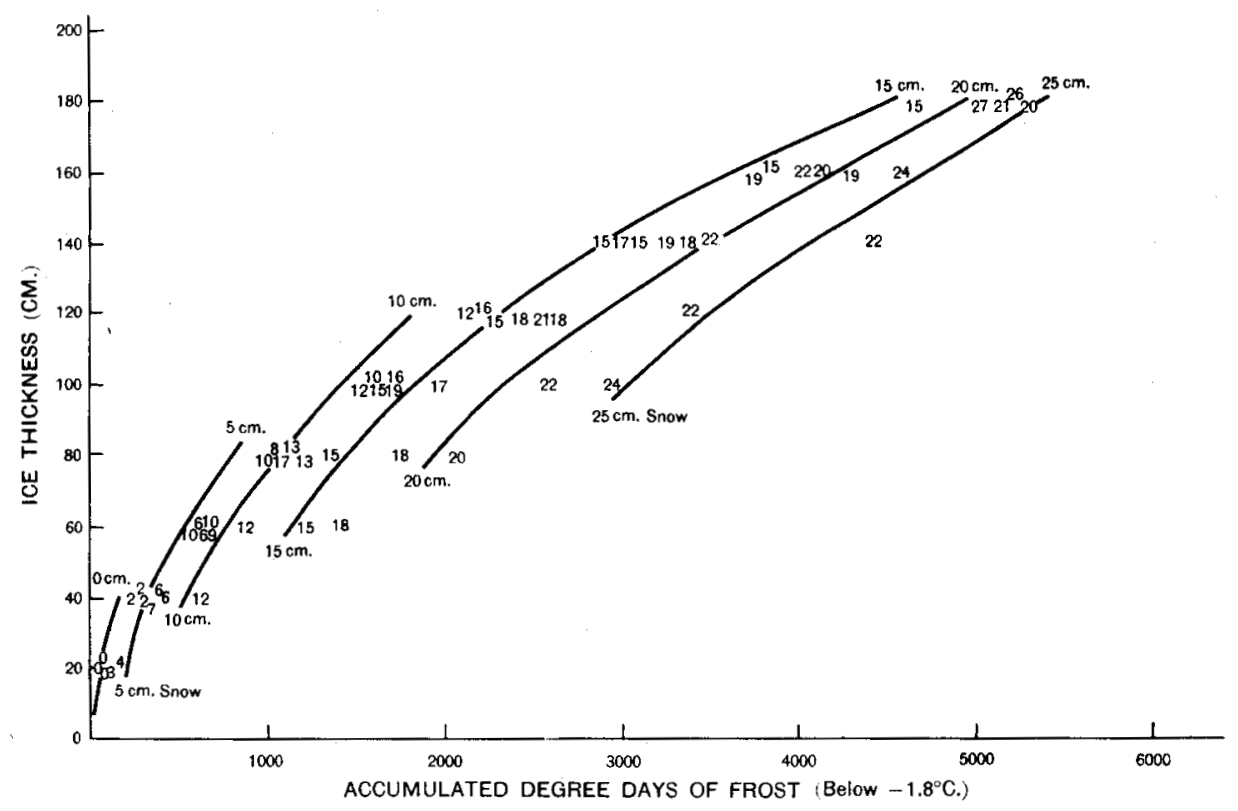

Fig. 10. Relationship between ice thickness, accumulated degree-days of frost (below $-1.8^{\circ} \mathrm{C}$.) and snow depth (numbers on curves) at Mould Bay.

V. V. Lebedev (1938) summarizes the results of several authors. The review includes theoretical expressions by Stefan and Tamura that exclude 


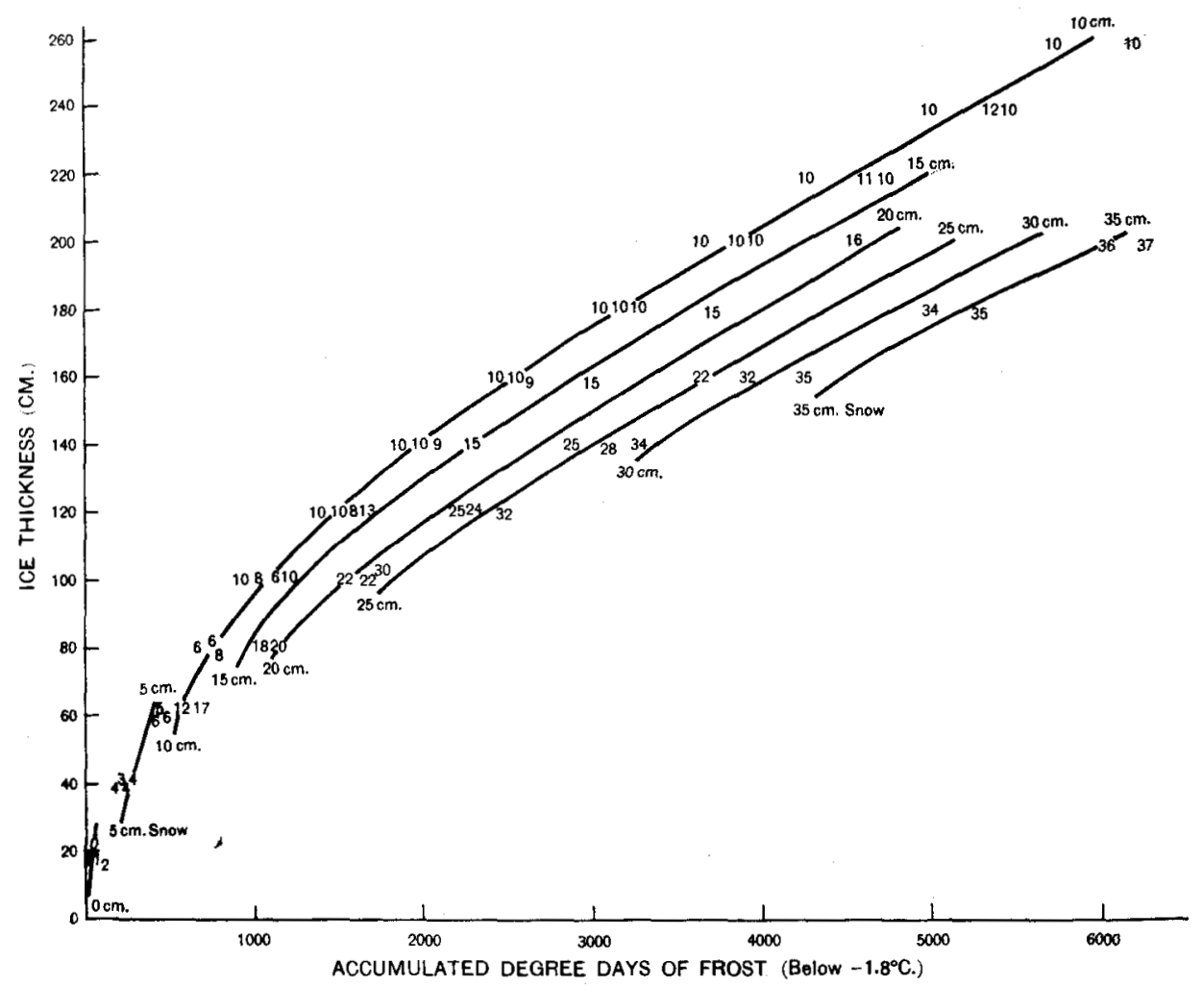

Fig. 11. Relationship between ice thickness, accumulated degree-days of frost (below $-1.8^{\circ} \mathrm{C}$.) and snow depth (numbers on curves) at Resolute.

the effect of a snow cover, and empirical equations by Karelin, Zubov, and others that take average snow conditions into account but make no attempt to evaluate its effect separately.

Using 19 stations in the Kara, East Siberian, Chukhotsk, Barents and Laptev seas for 24 station-years of observation, Lebedev found that the accretion of sea-ice (under average snow conditions) was related to the sum of negative mean daily air temperatures as follows:

$\mathrm{h}=1.33(\Sigma \theta)^{0.5 s}$

where: $\quad \mathrm{h}=$ thickness of ice in $\mathrm{cm}$. and

$\Sigma \theta=$ sum of negative air temperatures (below $0^{\circ} \mathrm{C}$.).

An equation of the same form:

$$
\mathrm{h}=1.53(\Sigma \theta)^{0.59}
$$

fits data obtained by Graystone (personal communication) in Button Bay near Churchill, Canada, when snow cover was negligible.

Curves representing these equations, as well as Zubov's (1945) expression

$$
\mathrm{h}^{2}+50 \mathrm{~h}=8 \mathrm{~s} \theta
$$

for stations in the Kara and Chukhotsk seas, and a composite curve for the five Canadian arctic localities in this study were compared (Fig. 12). Although derived from data for different areas the curves show similar shape. 
The average seasonal snow depth observed at the stations in this study is shown in Fig. 12.

Lebedev (1938) also introduces the formula:

$$
\mathrm{h}=(1.245)(\Sigma \theta)^{0.62}\left(\mathrm{~h}_{\mathrm{s}}\right)^{-0.15}
$$

which defines the dependence of ice accretion $h$ on negative air temperatures $\Sigma \theta$ (below $0^{\circ} \mathrm{C}$.) and the thickness of snow on the ice $h_{s}$ in $\mathrm{cm}$. Equation (4), however, was based on the data for only one year for fresh-water ice from the Yana River at Kazach'ye and the Kolyma River at Konzoboy in northeastern Russia.

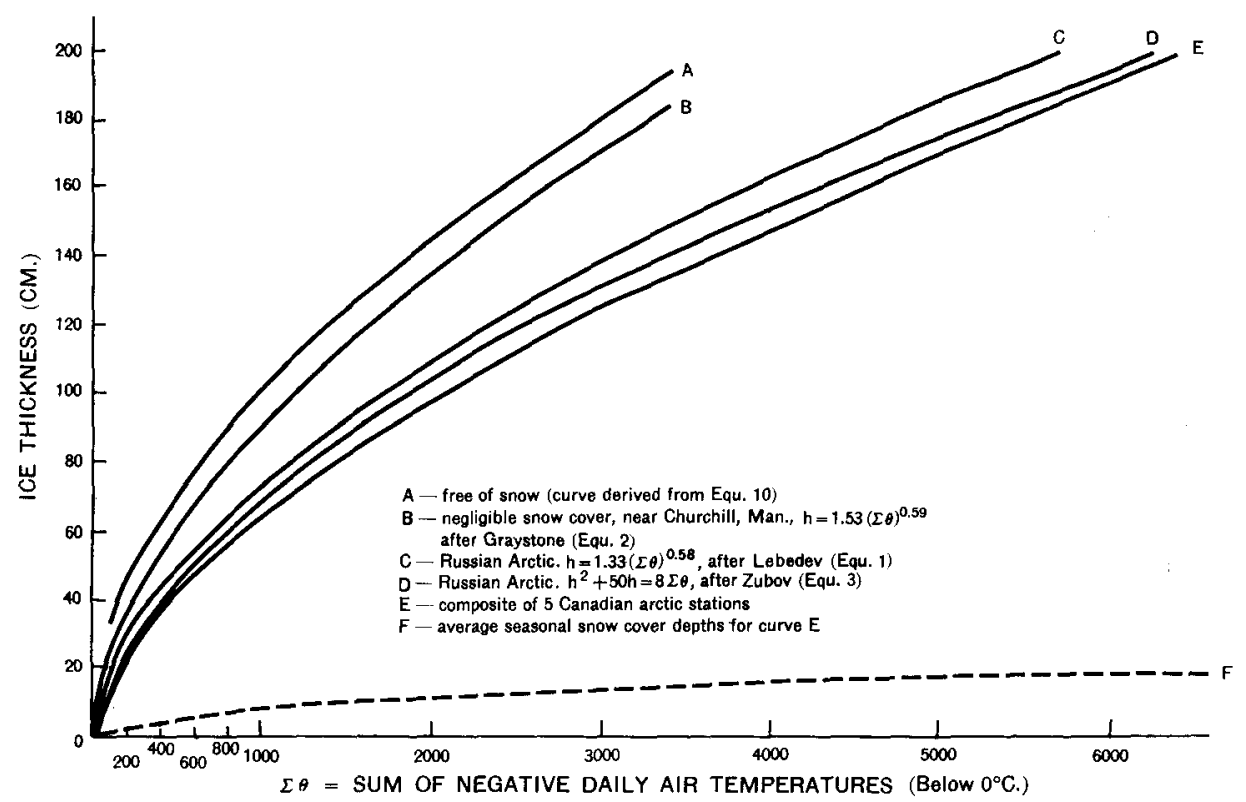

Fig. 12. Comparison of separate studies on accretion of sea-ice versus sum of daily negative air temperatures (below $0^{\circ} \mathrm{C}$.).

Assur (1956) presents the relation:

$$
\text { where: } \quad \begin{aligned}
\mathrm{h}= & (\mathrm{K}) 1.06 \mathrm{~V} \mathrm{~S} \\
\mathrm{~h}= & \text { ice thickness in inches, } \\
\mathrm{K}= & \text { coefficient, considering snow cover, stream flow, and } \\
\mathrm{S}= & \text { other local conditions, } \\
& \text { low } \left.32^{\circ} \mathrm{F} .\right) .
\end{aligned}
$$

This equation was developed for fresh-water ice but applied also as a first approximation for sea-ice.

The above equations permit the prediction of ice growth using air temperatures only, but no provision is made to compute increments of ice and no allowance is made for variations in snow depth. 


\section{A method for predicting sea-ice growth by increments using air temperatures and snow depths}

Assur presents an equation for computing increase of ice thickness in small increments, considering the insulating effect of different types of snow. (Assur 1956, eq. (4), p. 18). This equation expressed in simple terms for operational needs is actually a differential equation, which can be easily derived and modified for use as follows (personal communication).

As a first approximation from equation (5):

$$
\mathrm{h}^{2}=\mathrm{kS} \text {, }
$$

differentiating produces $2 \mathrm{hdh}=\mathrm{kdS}$ and setting $1 / \mathbf{k}=\mathbf{k}_{\mathrm{i}}$,

$$
\frac{\mathrm{dS}}{\mathrm{dh}}=2 \mathrm{k}_{\mathrm{i}} \mathrm{h} \text {. }
$$

Fig. 13. Regression to obtain $2 \mathrm{k}_{\mathrm{i}}$ and $2 \mathrm{k}_{\mathrm{i}} \mathrm{k}_{\mathrm{s}}$ for Alert.

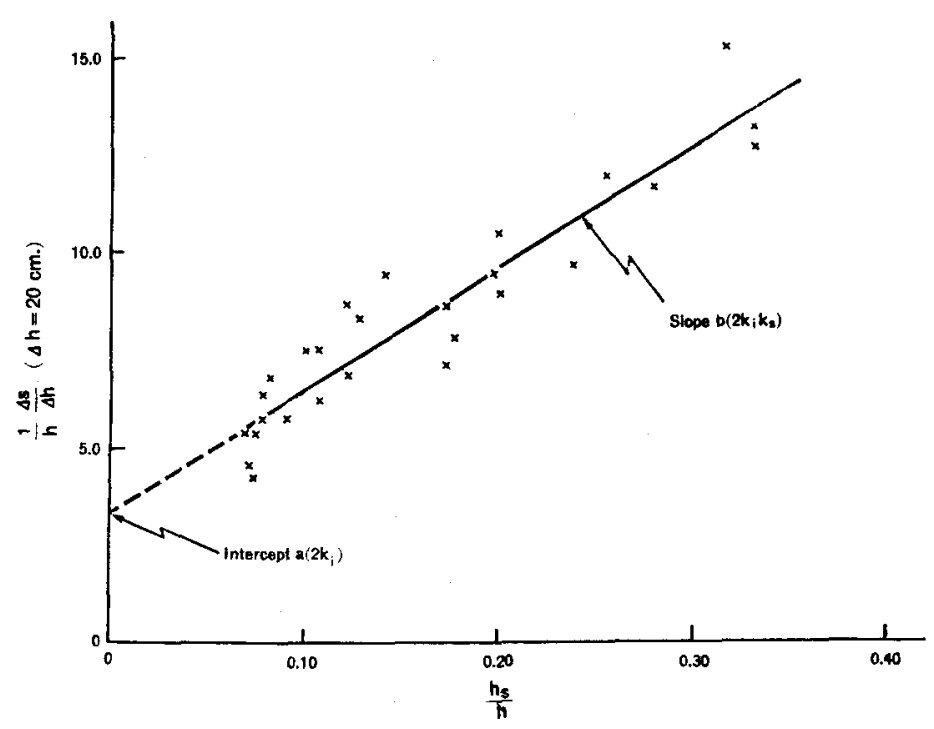

The change in ice thickness with respect to accumulated degree-days of frost at this point is dependent only upon ice thickness $h$. A snow layer of the thickness $h_{8}$ can be considered in its insulating effect as an equivalent ice layer $k_{\mathrm{g}} \mathrm{h}_{\mathrm{g}}$, and

$$
\frac{\mathrm{dS}}{\mathrm{dh}}=2 \mathrm{k}_{\mathrm{i}}\left(\mathrm{h}+\mathrm{k}_{\mathrm{s}} \mathrm{h}_{\mathrm{s}}\right)
$$

It is convenient to express (8) as

$$
\frac{1}{h} \cdot \frac{d S}{d h}=2 k_{i}+2 k_{i} k_{s} \cdot \frac{h_{s}}{h}
$$

and then to plot $\frac{1}{h} \cdot \frac{d S}{d h}$ against $\frac{h_{s}}{h}$. The coefficients are obtained 
from the slope, $b=2 k_{i} k_{s}$, and the intercept, $a=2 k_{i}$, of lines determined by least squares (Fig. 13). For ease of computing, differences $(\Delta)$ instead of differentials (d) were used. The terms are defined as follows:

$$
\begin{aligned}
& \Delta \mathrm{S}= \int_{\mathrm{t}_{1}}^{\mathrm{t}_{2}} \theta \mathrm{dt}, \text { accumulated degree-days of frost (below } \\
&-1.8^{\circ} \mathrm{C} \text {.) during the periods of ice accretion. } \\
& \mathrm{t}= \text { time in days, } \\
& \Delta \mathrm{h}= \mathrm{h}_{2}-\mathrm{h}_{1}, \text { amount of ice accreted (cm.) during the time } \\
& \text { interval } \Delta \mathrm{t} \text {. Intervals of } 20 \mathrm{~cm} \text {. of ice were found to be } \\
& \quad \text { most adequate for the analysis, } \\
& \mathrm{h}=\frac{\mathrm{h}_{1}+\mathrm{h}_{2}}{2}, \text { average thickness of the ice during accretion } \\
& \mathrm{h}_{\mathrm{S}}=\frac{\mathrm{h}_{\mathrm{S}_{1}}+\mathrm{h}_{\mathrm{S}_{2}}}{2} \text {, average thickness of the snow cover dur- } \\
& \text { ing accretion of } \Delta \mathrm{h}(\mathrm{cm} \text {.). }
\end{aligned}
$$

Table 3 gives the values for $2 \mathbf{k}_{1}$ and $2 \mathbf{k}_{1} \mathbf{k}_{\mathrm{s}}$, which are reduced to unity $(\Delta \mathrm{h}=1 \mathrm{~cm}$.$) .$

Table 3. Values of $2 \mathrm{k}_{\mathrm{i}}$ and $2 \mathrm{k}_{\mathrm{i}} \mathrm{k}_{\mathrm{s}}$

\begin{tabular}{lccc} 
& $\mathrm{a}=2 \mathrm{k}_{\mathrm{i}}$ & $\mathrm{b}=2 \mathrm{k}_{\mathrm{i}} \mathrm{k}_{\mathrm{s}}$ & $\mathrm{k}_{\mathrm{s}}=\mathrm{b} / \mathrm{a}$ \\
\hline Alert & 0.168 & 1.561 & 9.3 \\
Eureka & 0.160 & 1.348 & 8.4 \\
Isachsen & 0.148 & 0.651 & 4.4 \\
Mould Bay & 0.164 & 0.976 & 6.0 \\
Resolute & 0.156 & 1.152 & 7.4
\end{tabular}

Simplifications introduced in the derivation of (5) do not allow its use for thin ice (from 1 to $20 \mathrm{~cm}$.). Insufficient observations also prevented a detailed study of the growth of thin ice.

It should be noted that $\mathrm{b} / \mathrm{a}$ ( or $\mathrm{k}_{\mathrm{s}}$ ) represents the relative insulating effect of snow in comparison to ice. These values are in good agreement with an investigation on thermal insulating effects of different types of snow cover on the ice by Assur (1956). Since the constant $2 k_{1}$ is practically the same for all stations, accretion of sea-ice (except for thin sheets) that is free of snow is described approximately by the equation:

$$
\mathrm{h}^{2}=12.6 \mathrm{\Sigma} \theta \quad \text { (using a base of }-1.8^{\circ} \mathrm{C} \text {.). }
$$

A graphical representation of the above using a base of $0^{\circ} \mathrm{C}$. is shown in Figure 12.

The differences in the constant $k_{\mathrm{s}}$ can be attributed to variations in the density of the snow and other meteorological and oceanographic differences between stations.

Substituting the values of $2 \mathbf{k}_{\mathrm{i}}$ and $\mathrm{k}_{\mathrm{s}}$ into equation (8) provides an expression in differential form in which a separate term for the depth of snow on an ice sheet is introduced. For example, Resolute:

$$
\mathrm{dS}=\mathrm{dh} 0.156\left(\mathrm{~h}+7.4 \mathrm{~h}_{\mathrm{s}}\right) \text {. }
$$


To study a possible effect of the ice thickness on $2 k_{1}$ the differences between observed and computed points (Fig. 13) were plotted against the virtual ice thickness, $h+k_{s} h_{8}$. (Virtual ice thickness is the total relative insulating effect of the snow cover plus the ice sheet in terms of ice thickness. The relative insulating effect of snow, $k_{s}$, is obtained from the last column in Table 3.). Fig. 14 shows the result. The points represent arithmetic means of about 20 values each for the 3 points up to $100 \mathrm{~cm}$., about 50 values each for the 3 points up to $260 \mathrm{~cm}$., and 35 values each for the 2 points above $260 \mathrm{~cm}$. For virtual ice thicknesses greater than $90 \mathrm{~cm}$., the straight-line formula $\Delta\left(2 \mathrm{k}_{\mathrm{i}}\right)=0.027-0.00015\left(\mathrm{~h}+\mathrm{k}_{\mathrm{s}} \mathrm{h}_{\mathrm{s}}\right)$, obtained by

Fig. 14. Differences between observed and computed points of $2 \mathrm{k}_{\mathrm{i}}$ versus virtual ice thickness

$\left(\mathrm{h}-\mathrm{k}_{\mathrm{s}} \mathrm{h}_{\mathrm{s}}\right)$.

$\Delta\left(2 k_{i}\right)=$ departures of the observed values of $\mathbf{2} \mathbf{k}_{\mathrm{i}}$ from the regression lines (e.g., Fig. 13).

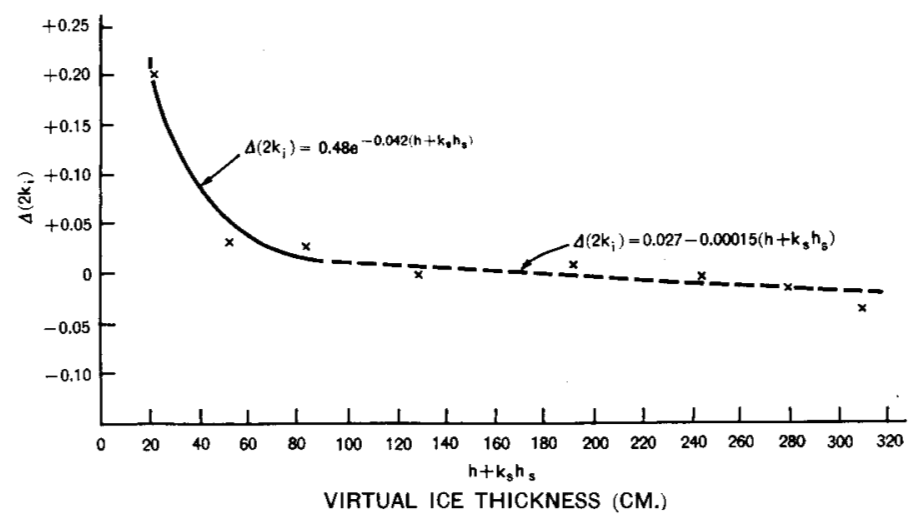

least squares shows that no adjustments to the constant $2 \mathbf{k}_{\mathbf{i}}$ are necessary. For virtual ice thicknesses between 20 and $90 \mathrm{~cm}$., however, the correction $\Delta 2 \mathrm{k}_{\mathrm{i}}$ to be added to the constant $2 \mathrm{k}_{\mathrm{i}}$ in Table 3 is

$$
\Delta\left(2 \mathrm{k}_{\mathrm{i}}\right)=0.48 \mathrm{e}^{-0.042\left(\mathrm{~h}+\mathrm{k}_{\mathrm{s}} \mathrm{h}_{\mathrm{s}}\right)}
$$

Equation (12) was derived by a visual fit on a semi-log plot.

\section{Decrease in sea-ice thickness and equations for predicting it using air temperatures}

Few investigations have been made of the rate at which sea-ice decreases in thickness. Most of the literature on the subject relates to the break-up of rivers and lakes for navigational purposes (Zubov 1945, Burbidge and Lauder 1957). These studies are based on observations of deteriorating ice conditions rather than measurements of the decrease in ice thickness.

Theoretical equations similar to those available for sea-ice growth have not been developed for the decay process. The many physical and mechanical variables which affect sea-ice decay, and also lack of methods and instrumentation, apparently have prevented the investigation of the problem. 
Table 4. Decrease in sea-ice thickness and accumulated degree-days (above $-1.8^{\circ} \mathrm{C}$.)

\begin{tabular}{|c|c|c|c|c|c|}
\hline Station & Year & Date & $\begin{array}{c}\text { Ice thickness } \\
(\mathrm{cm} .)\end{array}$ & $\begin{array}{c}\text { Total decrease } \\
\text { in ice thickness } \\
(\mathrm{cm} .)\end{array}$ & $\begin{array}{c}\text { Accumulated } \\
\text { degree days } \\
\left(\text { above }-1.8^{\circ} \mathrm{C} .\right)\end{array}$ \\
\hline \multirow[t]{4}{*}{ Eureka } & 1951 & $\begin{array}{lr}\text { June } & 1 \\
\text { June } & 18 \\
\text { June } & 25 \\
\text { July } & 2 \\
\text { July } & 9 \\
\text { July } & 17\end{array}$ & $\begin{array}{r}231.1 \\
212.1 \\
170.2 \\
127.0 \\
88.9 \\
63.5\end{array}$ & $\begin{array}{r}19.0 \\
60.9 \\
104.1 \\
142.2 \\
167.6\end{array}$ & $\begin{array}{r}57 \\
107 \\
174 \\
235 \\
286\end{array}$ \\
\hline & 1950 & $\begin{array}{lr}\text { June } & 5 \\
\text { June } & 16 \\
\text { June } & 28 \\
\text { July } & 4\end{array}$ & $\begin{array}{l}261.6 \\
238.8 \\
162.6 \\
137.2\end{array}$ & $\begin{array}{r}22.8 \\
99.0 \\
124.4\end{array}$ & $\begin{array}{r}40 \\
109 \\
155\end{array}$ \\
\hline & 1949 & $\begin{array}{l}\text { May } 15 \\
\text { June } 16 \\
\text { July } 8\end{array}$ & $\begin{array}{l}255.3 \\
198.1 \\
137.2\end{array}$ & $\begin{array}{r}57.2 \\
118.1\end{array}$ & $\begin{array}{r}91 \\
233\end{array}$ \\
\hline & 1948 & $\begin{array}{l}\text { May } 25 \\
\text { June } 16\end{array}$ & $\begin{array}{l}228.6 \\
172.7\end{array}$ & 55.7 & 67 \\
\hline \multirow[t]{4}{*}{ Isachsen } & 1956 & $\begin{array}{lr}\text { May } & 2 \\
\text { July } & 22 \\
\text { July } & 29 \\
\text { Aug. } & 1 \\
\text { Aug. } & 5 \\
\text { Aug. } & 19\end{array}$ & $\begin{array}{r}203.2 \\
132.1 \\
121.9 \\
114.3 \\
104.1 \\
96.5\end{array}$ & $\begin{array}{r}71.1 \\
81.3 \\
88.9 \\
99.1 \\
106.7\end{array}$ & $\begin{array}{l}132 \\
162 \\
189 \\
213 \\
245\end{array}$ \\
\hline & 1954 & $\begin{array}{ll}\text { June } & 1 \\
\text { July } & 1\end{array}$ & $\begin{array}{l}231.1 \\
215.9\end{array}$ & 15.2 & 82 \\
\hline & 1951 & $\begin{array}{ll}\text { June } & 4 \\
\text { Aug. } & 4\end{array}$ & $\begin{array}{l}268.0 \\
121.9\end{array}$ & 146.1 & 262 \\
\hline & 1948 & $\begin{array}{l}\text { May } 14 \\
\text { May } 25\end{array}$ & $\begin{array}{l}213.4 \\
198.1\end{array}$ & 15.3 & 31 \\
\hline \multirow[t]{2}{*}{ Mould Bay } & 1951 & $\begin{array}{l}\text { June } 11 \\
\text { June } 13 \\
\text { July } 9\end{array}$ & $\begin{array}{l}221.1 \\
215.9 \\
127.0\end{array}$ & $\begin{array}{r}5.1 \\
94.0\end{array}$ & $\begin{array}{r}9 \\
142\end{array}$ \\
\hline & 1948 & $\begin{array}{l}\text { June } 21 \\
\text { July } 16\end{array}$ & $\begin{array}{l}177.8 \\
139.7\end{array}$ & 38.1 & 125 \\
\hline \multirow[t]{3}{*}{ Resolute } & 1955 & $\begin{array}{l}\text { June } 15 \\
\text { June } 20\end{array}$ & $\begin{array}{l}181.1 \\
178.1\end{array}$ & 3.0 & 14 \\
\hline & 1954 & $\begin{array}{lr}\text { June } & 28 \\
\text { July } & 5 \\
\text { July } & 12 \\
\text { July } & 20 \\
\text { July } & 26\end{array}$ & $\begin{array}{r}199.1 \\
182.6 \\
143.7 \\
120.9 \\
96.8\end{array}$ & $\begin{array}{r}16.5 \\
55.4 \\
78.2 \\
102.3\end{array}$ & $\begin{array}{r}36 \\
106 \\
141 \\
178\end{array}$ \\
\hline & 1950 & $\begin{array}{l}\text { June } 16 \\
\text { June } 20 \\
\text { July } 4\end{array}$ & $\begin{array}{l}194.3 \\
189.2 \\
162.6\end{array}$ & $\begin{array}{r}5.1 \\
31.7\end{array}$ & $\begin{array}{l}16 \\
80\end{array}$ \\
\hline
\end{tabular}


No emphasis was placed on continuing ice thickness observations during the ablation period at the stations. However, sufficient measurements were made to justify an analysis of the relationship between the decrease of sea-ice thickness and air temperatures.

The observed decrease of ice thickness and concurrent accumulated degree-days are given in Table 4 for 4 of the stations in this study. Accumulated degree-days are obtained by summing the difference between $-1.8^{\circ} \mathrm{C}$. and each mean daily air temperature above $-1.8^{\circ} \mathrm{C}$. The base of $-1.8^{\circ} \mathrm{C}$. was used because it approximates the freezing point of the seaice in this area, and (as will be shown) statistically provides the best base for the analysis.

Fig. 15. Relationship between decrease in seaice thickness and accumulated degree-days (above $-1.8^{\circ} \mathrm{C}$.)

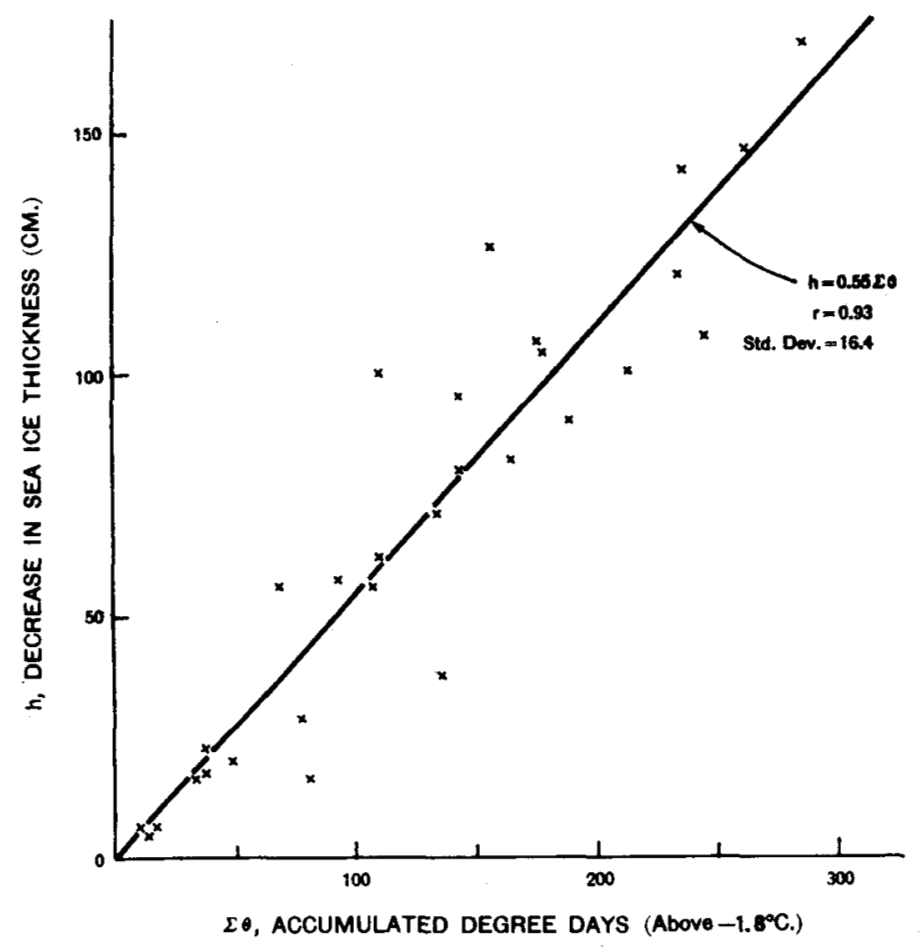

The 29 observations on decreasing sea-ice thicknesses are plotted against accumulated degree-days in Fig. 15. A least squares computation on the variables yielded a correlation coefficient of 0.93 ; and a standard deviation of $16.4 \mathrm{~cm}$. The relationship is

$$
\begin{aligned}
& \mathrm{h}=0.55 \Sigma \theta \\
& \text { where: } \quad \mathrm{h}=\text { decrease in ice thickness }(\mathrm{cm} .) \text {, and } \\
& \Sigma \theta=\text { accumulated degree days above }-1.8^{\circ} \mathrm{C} \text {. }
\end{aligned}
$$

D. B. Karelin as quoted by Armstrong (1955) developed the formula

$$
\mathrm{h}=0.51(\Sigma \theta-32)
$$

where: $\quad \mathrm{h}=$ thickness of ice thawed in $\mathrm{cm}$., and

$$
\Sigma \theta=\text { sum of average daily air temperatures over }-5.0^{\circ} \mathrm{C} \text {. }
$$


No information was presented on the quantity of data used in development of the empirical equation. The source of the data, as indicated by the reference title, apparently was in the Russian Arctic.

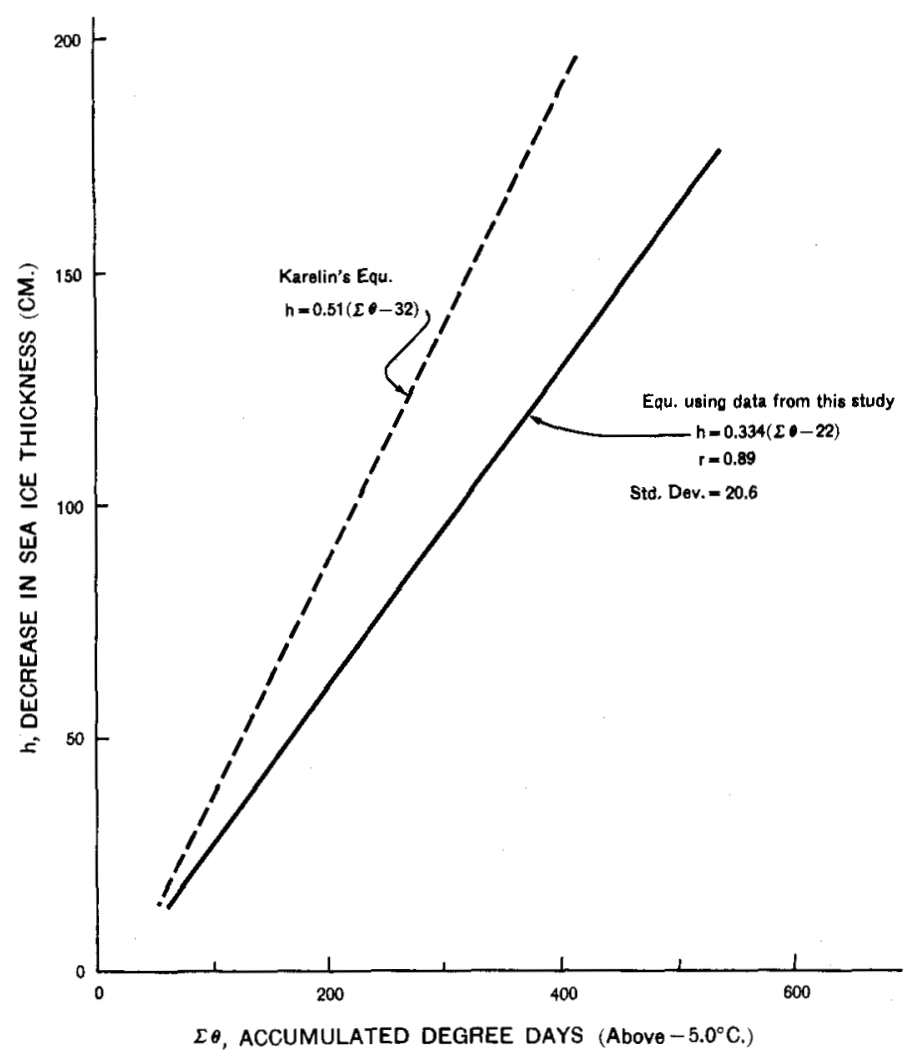

Fig. 16. Comparison of equations that associate decrease in sea-ice thickness with accumulated degree-days (above $-5.0^{\circ} \mathrm{C}$.).

Employing the base of $-5.0^{\circ} \mathrm{C}$. used by Karelin the data in this study gave the equation, determined by least squares,

$$
\mathrm{h}=0.334(\Sigma \theta-22) \text {. }
$$

Comparing this equation with Karelin's (Fig. 16) reveals that the Canadian Arctic apparently requires more accumulated degree-days for increasing amounts of ice decay than the Russian Arctic. The results show also that a base of $-1.8^{\circ} \mathrm{C}$. yields a higher correlation coefficient than a base of $-5.0^{\circ} \mathrm{C}$. (0.93 against 0.89$)$, and a smaller standard deviation (16.4 against $20.6 \mathrm{~cm}$.).

\section{Acknowledgements}

The data used in this report were made available through the combined efforts of personnel associated with the Meteorological Branch of the Canada Department of Transport and the U. S. Weather Bureau.

The author wishes to thank Dr. Andrew Assur for his valuable assistance with the sections on predicting sea ice growth, Mrs. Genevieve Hacker 
for her assistance with the computation and tabulation of the data, Mrs. Evelyn Duncan-Clark for the secretarial work, and Dr. R. W. Gerdel for his review of the paper.

\section{Appendix A}

Areas and bodies of water studied:

Alert $\left(82^{\circ} 30^{\prime} \mathrm{N} .62^{\circ} 20^{\prime} \mathrm{W}\right.$. $)$ is located on Parr Inlet in the northeast corner of Ellesmere Island, N.W.T., Canada. A narrow constriction separates Parr Inlet from Dumbell Bay. To the north of Dumbell Bay is the Lincoln Sea and the Arctic Ocean.

The ice thickness measurements were made at the center and occasionally at the mouth of Parr Inlet. The depth of water at about 200 metres off shore in Parr Inlet is approximately 14 metres.

Eureka $\left(79^{\circ} 59^{\prime}\right.$ N. $85^{\circ} 57^{\prime} \mathrm{W}$.) is on the northern shore of Slidre Fiord. The fiord runs east-southeastward from Eureka Sound, which is located between Axel Heiberg and Ellesmere islands (Fig. 1).

The ice measurements were made in Slidre Fiord at 150 to 300 metres from the shore line where the depth of water is between 23 and 61 metres.

Isachsen $\left(78^{\circ} 47^{\prime} \mathrm{N} .103^{\circ} 32^{\prime} \mathrm{W}\right.$.) is on Deer Bay on the west coast of Ellef Ringnes Island. Peninsulas that extend westward to the north and south of the station form this relatively large bay. To the southwest of Deer Bay is the Prince Gustaf Adolf Sea and to the northwest the Arctic Ocean.

The ice measurements were made in Deer Bay at 100 to 500 metres off-shore where the water is 12 to 30 metres in depth.

Mould Bay $\left(76^{\circ} 14^{\prime}\right.$ N. $119^{\circ} 20^{\prime}$ W. ) is located on Mould Bay on the southeast coast of Prince Patrick Island. This bay runs north-south and is approximately 40 kilometres long and 6 kilometres wide. The bay opens into Crozier Channel to the south.

The ice measurements were made in Mould Bay at 150 to 800 metres off-shore where the water is from 6 to over 30 metres in depth.

Resolute $\left(74^{\circ} 41^{\prime}\right.$ N. $94^{\circ} 54^{\prime} \mathrm{W}$.) is on Resolute Bay on the southern coast of Cornwallis Island. To the southeast and southwest of Resolute Bay are the waters of Barrow Strait.

The ice measurements were made in Resolute Bay at 100 to about 875 metres from shore, where the depth of water is from 6 to 16 metres.

\section{Appendix B}

\section{Techniques used to measure sea-ice thickness}

During the first years of operation, ice thickness was measured through holes chipped out with chisels. On occasion dynamite was used to blast through the upper part of thick ice, and the hole was finished with chisels.

An electrical-mechanical method for measuring ice thickness was introduced by Polar Operations, U. S. Weather Bureau, in 1953-4, at the arctic. stations. The apparatus consists of a portable power source and a wire loop going through the ice into the water below. The wire carries an umbrella shaped device under the ice sheet. Electric power is applied to heat the wire 
which melts free, permitting it to be lifted until the umbrella device touches the bottom of the ice.

This method was used with success prior to 1956. In one case (Resolute, 1955-6), a wooden box was used to shelter the apparatus. The snow accumulation about this box was markedly different from the natural snow cover so no reliable analysis on ice growth could be made for that year.

To facilitate the making of these ice observations and to improve the accuracy of the measurements, a standard hand-operated ice auger developed by SIPRE was assigned to each station in April 1956. When proper precautions are applied, this auger permits drilling of a 1-inch hole through thick ice in a short time. To measure the ice thickness, a measuring tape with a short section of rod attached to its end is lowered into the hole. When the rod is below the ice sheet, it swings to a horizontal position. The rod is then lifted until it stops at the undersurface of the ice and the thickness of the ice is observed. A separate wire attached to the end of the rod is used to draw the rod and tape back through the hole.

\section{References}

Anon. 1947-57. Canada Dept. of Transport Meteor. Branch, Toronto. Records of Meteor. Observations, form 2301.

1948-50. Climatological Summary for Eureka, N.W.T., Canada (January

1948-December 1950). U. S. Weather Bur., U. S. Dept. of Commerce.

1954. Canada Dept. of Transport Meteor. Branch, Toronto. Monthly Record,

Meteor. Observations in Canada.

Armstrong, T. 1955. Soviet work on sea ice forecasting. Polar Record No. 49:302-11.

Assur, A. 1956. Airfields on floating ice sheets. SIPRE Rep. 36. Snow Ice and Permafrost Res. Est., Corps of Eng., U. S. Army, Wilmette.

Burbidge, F. G. and J. R. Lauder. 1957. A preliminary investigation into break-up and freeze-up conditions in Canada. Circ. 2939, T-252. Canada Dept. of Transport Meteor. Branch.

Bydin, F. I. 1933. Zimnii rezhim rek i metody ego izucheniia. Issledovaniia rek SSSR, Gosudarstvennyi gidrologicheskii institut. 5: 5-237.

Callaway, E. B. 1954. An analysis of environmental factors affecting ice growth. Tech. Rept. 7. Hydrographic Office, Washington. 30 pages.

Fukutomi, T. 1950. Kaihyo no kenkyu, dai-san-po. English summary. (Study of sea ice, Third Report). Teion-kagaku 3:131-42.

1955. Kaihyo no kenkyu (dai 19 ho). English summary. (Study of sea ice, 19th Report). Teion-kagaku 11. Transl. IR 747-55. 1955. Air Intelligence Information.

Kolesnikov, A. G. 1946. K teorii narastaniia l'da na poverkhnosti moria. Trudy NauchnoIssledovatel'skikh Uchrezhdenii Ser. V, 12: 109-47.

Lebedev, Vl. V. 1938. Rost l'da $\mathrm{v}$ arkticheskikh rekakh $\mathrm{i}$ moriakh $\mathrm{v}$ zavisimosti ot otritsatel'nykh temperatur vozdukha. Problemy arktiki 5-6:9-25.

Lee, O. S. and L. S. Simpson. 1954. A practical method of predicting sea ice formation and growth, Tech. Rep. 4. Hydrographic office, Washington. 27 pages.

Rodhe, B. 1952. On the relation between air temperature and ice formation in the Baltic. Geografiska annaler 34:175-202.

Sverdrup, H. U., M. W. Johnson and R. H. Fleming. 1942. The oceans, their physics, chemistry and general biology. New York: Prentice-Hall. 1087 pages.

Taylor, Andrew. 1955. Geographical discovery and exploration in the Queen Elizabeth Islands. Ottawa: Queen's Printer. 172 pages.

Zubov, N. N. 1945. L'dy arktiki. Moskva: Izd-vo. Glavsevmorputi. 360 pages. 